\title{
The Value Guidance and the Cultivation of Legal Belief in the Education of College Students' Rule of Law in the Era of Media
}

\author{
Xiao Yin \\ Zhejiang Open University, Hangzhou, China \\ Email: 357139169@qq.com
}

How to cite this paper: Yin, X. (2021) The Value Guidance and the Cultivation of Legal Belief in the Education of College Students' Rule of Law in the Era of Media. Open Access Library Journal, 8: e7556. https://doi.org/10.4236/oalib.1107556

Received: May 20, 2021

Accepted: June 22, 2021

Published: June 25, 2021

Copyright $\odot 2021$ by author(s) and Open Access Library Inc.

This work is licensed under the Creative Commons Attribution International License (CC BY 4.0).

http://creativecommons.org/licenses/by/4.0/

\section{(c) (i) Open Access}

\begin{abstract}
With the development of the Internet, we media era has become a new trend of development, but the development of we media era also brings many disadvantages. We media has a certain degree of virtuality and concealment, so it gives some lawbreakers an opportunity to take advantage of. College students, as an important group to be built in the future of the country, It is very important to guide the value of legal education and cultivate legal belief for college students. However, the education of rule of law is a long-term strategy, which cannot be achieved overnight. Instead, we should establish systematic thinking, innovate according to the situation, coordinate and promote with the actual situation of students, and cultivate a group with the correct value system.
\end{abstract}

\section{Subject Areas}

Higher Education

\section{Keywords}

College Students, Law Education, Value Guidance, Legal Belief

\section{Introduction}

In his meeting on College Students' rule of law education, Secretary Xi Jinping emphasized that the relationship between high rule of law education and what kind of people should be cultivated and how to train people is the fundamental issue. We should persist in taking value guidance as the central link, run the rule of law education through the whole process of College Students' education, and cultivate a correct value system and legal belief system for college students. "This 
points out the direction for the development of College Students' legal education. In reality, both the school and the society should implement it from the practical level, rather than just a mere formality. They should always adhere to the systematic thinking mode, constantly adhere to the cultivation and implementation of the systematic project construction of the rule of law education, and inject the value guidance and legal belief of the rule of law education into the whole value system of college students, so as to cultivate high-quality talents for the country [1].

\section{New Requirements of College Students' Legal Education in We Media Era}

With the convening of the 19th National Congress of the Communist Party of China, China has achieved a new leap in socialism, and the rule of law education in China has also been put on the new agenda. The rule of law education should penetrate into all aspects of College Students' life. In the development of the rule of law education, we should put the value guidance and legal belief of the rule of law education throughout all aspects of college students, and increase the cultivation of the value system of the rule of law education for college students. In the era of we media, although contemporary college students can access Internet information and expand their knowledge and vision, However, it is inevitable that some contents of the Internet also make college students who are not deeply involved in the world lose themselves, and the value system is wrongly induced. Therefore, it is a new requirement of the new era to strengthen the value guidance of College Students' legal education and the cultivation of legal belief. But nowadays, the value guidance of rule of law education is a long-term systematic work. It is not a school education, but a family education [2]. It involves all aspects of the whole education system and is very complex. In terms of the current situation of the value guidance and legal belief of the whole society for college students' legal education, there are still some problems, such as the low degree of social attention, the lack of a stable and mature system, and the single channel of its development. Therefore, how to effectively enhance the value guidance and Legal Belief Cultivation of college students in the era of we media is a difficult problem for today's academic circles.

\section{The Problems of Value Guidance and Legal Belief Cultivation in the Education of Rule of Law}

\subsection{Too Dependent on Higher Education, Lack of Cooperation}

In the we media era, legal education for college students mainly depends on the propaganda and education of colleges and universities, and the guidance of classroom teaching has become one of the main channels. Although it is also very important for the legal education of students, it cannot achieve the final effect by relying too much on the school and ignoring the value guidance and Legal Belief Cultivation of other subjects for the legal education of college students, 
Therefore, the study of the rule of law education for college students cannot blindly rely on Colleges and universities, family education and social education is also very important, need multi-party coordination, the three should be organic unity, in order to achieve good results. In real life, although the education department is also aware of this problem and has begun to infiltrate the value guidance and legal belief of the rule of law education into all aspects of society, its system and mechanism are not perfect, students' attention is still focused on the classroom, and some families and society do not attach great importance to the value guidance and Legal Belief Cultivation of the rule of law education, It is lack of value guidance and Legal Belief Cultivation in the effective multi-party coordination of legal education, lack of in-depth exploration and thinking, and lack of work motivation [3]. It only relies on the school for propaganda and cultivation, while the school mainly popularizes it through classroom teaching and other means. The form is too monotonous and inflexible, and the whole process lacks flexibility, therefore, with the development of the new era, it is more and more difficult for the old rigid legal education and publicity to cope with the new challenges in the new era.

\subsection{The Education of the Rule of Law Is Extensive and Lacks of Individuality}

In the process of value guidance and Legal Belief Cultivation of College Students' legal education, it is mainly carried out through two aspects: one is mainly through the publicity of legal education in Colleges and universities, in the form of campus activities, and the other is through classroom teaching. The cultivation of this system is mainly carried out through the class, because the class as a group, each person's character, thought, cognitive ability and knowledge base are different. If only relying on counselors to understand, human resources are limited, it is impossible to fully understand each person's character, thought and so on, and the teaching form is unified teaching, large class teaching. There are still some problems in the communication of legal education. In recent years, the personality of students has become more and more distinct, and education should be individualized according to the characteristics of each student. However, due to the limited distribution of resources and insufficient attention to the rule of law education, there is a lack of effective means and mechanism for the value guidance and Legal Belief Cultivation in the rule of law education. At the same time, the content and form of the rule of law education carried out by various departments are not equal to the personalized characteristics of students, so it is difficult to achieve accurate coordination and let each student promote the personalized implementation plan [4].

\subsection{Network Education Is Fighting Itself and Lacks of Overall Linkage}

With the advent of we media era and the in-depth development of mobile Internet, the network has become one of the information receiving channels that col- 
lege students often contact in the new era. The education and teaching platform also began to change the traditional classroom input mode, and began to use the Internet for information exchange and transmission, which has become the main way for the society to carry out the rule of law education, The application of various Internet platforms has become the norm of value guidance and Legal Belief Cultivation in the rule of law education. For example, the cloud platform of rule of law education is the main way of learning and education, which plays an important role in the cultivation of value system in the rule of law education. However, due to the characteristics of the network itself, there are many difficulties in the publicity of the rule of law education. One of them is that the network communication is open, and there are great uncertainties in its popularization scope and contact frequency. Because the resources contacted by college students are effective, the network education often goes its own way, Lack of integration, each platform is set up separately, like an information island, they are separated from each other, lack of integration and linkage, and their role is limited. One of the reasons is that network communication is open, and there are great uncertainties in its popularization scope and contact frequency [5]. Because the resources that college students are exposed to are effective, network education tends to work independently and lacks integration. Each platform is set up separately, like an information island. They are separated from each other and lack integration and linkage, the role played is also limited. If the platform is set up separately, it is like an information island. They are separated from each other, lack integration and linkage, and play a limited role. If the platform is set up separately, it is like an information island. They are separated from each other, lack integration and linkage, and play a limited role.

\section{The Content of Value Guidance and Legal Belief Cultivation in the Education of Rule of Law}

The rule of law education is one of the guidance of College Students' value system. The legal education of college students has both the generality and the particularity of legal education. The main body of legal education is college students, and the legal education of college students is mainly carried out in the form of teaching. The content of the legal education of college students mainly includes two aspects: legal knowledge and value guidance [6].

\subsection{Legal Knowledge}

The so-called legal knowledge refers to the general term of the basic legal knowledge and experience acquired by the educated in the process of practice and theoretical learning. It contains a series of legal knowledge such as jurisprudence and constitution. This enables college students to understand the basic knowledge of law, so as to provide a certain legal belief for the whole legal practice of college students [7]. The common sense of law is a basic work and a long-term systematic project, which makes the most basic bottom line for the value guid- 
ance of college students. It is the bottom line for students to know what should be done and what should not be touched.

\subsection{Value Guidance}

The ability of rule of law education is that the actor uses legal norms to guide people's values. By using rule of law education, college students should establish correct values, understand how to use legal knowledge to guide and regulate their own behavior, and encourage students to actively participate in the practice of rule of law to improve their ability. We should guide students to use their power correctly, fulfill their obligations, consciously resist the temptation of society, and use their own legal knowledge to defend their legitimate rights. The ultimate goal is to ensure that students should strengthen their own beliefs, form correct values, resist temptation, and learn to use the law to solve conflicts and disputes. These are the correct values that college students should guide in the rule of law education [8].

The cultivation of the rule of law education is not only an important work of colleges and universities, but also a good atmosphere that all sectors of society need to create, which needs the support of the state, society, family and other aspects. We should always stand at the political height, cooperate with colleges and universities, and provide a good guarantee for the development of the rule of law education for college students. It is necessary to issue relevant opinions and suggestions on the value guidance and Legal Belief Cultivation in the rule of law education as soon as possible. All sectors of the society should implement seamless docking with the development of the rule of law education in Colleges and universities, fully support the development of the rule of law education, and realize the coordinated development of online and offline Secondly, in the era of we media, the value guidance and cultivation of legal belief in legal education involve many social fields. In the new era, the state should also establish various guarantee mechanisms for the development of legal education. In the process of legal education, legal education should run through all aspects of students' education and teaching life, and create a strong legal atmosphere according to the actual situation of students, We should try our best to provide good service for the development of College Students' rule of law education, guide students to establish correct concept of rule of law, cultivate students' habit of rule of law, and deal with illegal behaviors in society with the weapon of law.

\section{Countermeasures to Promote Value Guidance and Legal Belief Cultivation in the Education of Rule of Law}

\subsection{In Depth Implementation of the "Ability Improvement Project", Grasp the Direction, Overall Planning, the First Thing to Do Is to Be Hard}

One of the important ways to do well in the value guidance and Legal Belief Cultivation of College Students' legal education is to strengthen the party's leader- 
ship, grasp the direction, and coordinate the overall situation. In the deep implementation of the "project to improve the ability of the rule of law", we should first grasp the idea, establish a correct legal concept, focus on the toplevel design, strengthen the ability of the rule of law, put the responsibility of each stage in place, and remember to shirk or become a mere formality [9]. First, we should strengthen and improve the ideological construction of the school management department, constantly improve and consolidate the construction of the system and mechanism, from the attention of the leadership to the value guidance of College Students' rule of law education, and constantly promote it at the grassroots level. Second, it is necessary to gradually form a system of overall planning, joint promotion and collaborative education of leaders at all levels and departments, vigorously promote the value guidance of legal education and the cultivation of legal belief, highlight the changes in the ideological field of the rule of law, always firm the ideological consciousness, and improve the legal value and belief of college students. Third, it is necessary to implement the main responsibility of the relevant departments of the school, firmly grasp the leading power of ideology, follow the responsibility consciousness of various ideologies, strengthen the leading role in important issues, firmly grasp the political direction of the party, and resolutely and favorably implement the major policies of the whole Party and the country [10]. It will be refined and infiltrated into the legal education and cultivation of college students. The fourth is to improve the awareness of the rule of law, constantly strengthen the ability of the rule of law education, carry out various activities in the school, such as reports, seminars and various lectures, and constantly strengthen the value guidance and the promotion of Legal Belief Cultivation in the rule of law education through the rich campus life, which is an important path to improve the rule of law education system. Fifthly, we can't relax the campus propaganda work. We should strengthen the campus propaganda work at the right time, carry out all kinds of propaganda of the rule of law education, regularly study and discuss the popularization of the rule of law education for college students, improve its shortcomings, refine the division of responsibilities, focus on the value of the direction and goal of discipline construction, and put the rule of law education into practice [11].

\subsection{Implement the "Safeguard Mechanism Project" in Depth, Integrate Resources and Promote in Coordination}

The implementation of the rule of law education for college students is based on a certain national system. In order to ensure the construction of the project of legal education, the establishment of rules and regulations is very important. So, in combination with the current situation, the mechanism should be flexible and adapt to social development. The outline of the education for the rule of law for adolescents should be interpreted in terms of the importance and urgency of rule of law education [12]. It points out that the establishment of the rule of law education system is a multi-faceted responsibility of society, the state, the school and the family, and it is necessary to cooperate, but not all depends on the propa- 
ganda of the school. Therefore, the value guidance of the education of rule of law and the cultivation of legal belief should be carried out in a coordinated way. With the development of the era of self media, self media has become a resource which cannot be ignored at present. The state should keep pace with the times, make full use of its advantages and resources, and adjust its strategy constantly in combination with the actual development of college students. To innovate the education mode, we should combine with traditional teaching forms to promote the development of legal education. In twenty-first Century, this generation of college students grew up with the Internet [13]. Therefore, the rule of law education should also face the new situation of modern network education, make full use of the self media platform, take Xi Jinping thought as the guide, and open up the rule of law education column, establish the rule of law several Oh, and the special website to carry out the learning and communication of students' knowledge of rule of law education.

\subsection{Carry out the "Soul Casting Project" in Depth, Strengthen the Foundation and Consolidate the Strength}

In his speech, $\mathrm{Xi}$ Jinping came to the conclusion that "adhering to ideals and beliefs is the most basic task of a nation and a nation." ideals and beliefs are the soul and direction of a nation. It is the spiritual motive force for the development of young people. It is a concentrated expression of the world outlook and life values. Firm ideals and beliefs are not spontaneous actions. This is the gradual formation of ideology in the late edification of education. Therefore, the cultivation of the rule of law education should understand the party's legal knowledge and legal consciousness of the young students, so that the students not only learn to know, but also learn to use, and always put the value guidance in the first place of the whole work. It is necessary to strengthen the value guidance and Legal Belief Cultivation of College Students' legal education, put the important spiritual concept of legal education into students' daily learning, constantly guide students to study deeply and deeply understand the legal belief of legal education, combine with students' own reality, establish correct values, and lay the foundation for the formation of students' legal thought. Second, we should always grasp the leading role of the rule of law education, constantly promote the process of ruling the country by law of socialism with Chinese characteristics, integrate the thought of rule of law education with the value system of students, make the scientific legal value system become the guide for the growth of students, and constantly pursue the spiritual purification and ideological strengthening. Third, we should continue to strengthen the training of the leading group in Colleges and universities, let the leading cadres play a leading role, take the lead in strengthening their ideals and beliefs, take the lead in improving their legal thinking ability, let the leading cadres set a practical example, and let the students have a new understanding of the cultivation of correct values and legal beliefs from the bottom of their hearts. The fourth is to implement the student promotion plan and strengthen the construction of key work areas. 
By continuously promoting the key work plan, we can help students build spiritual support. Through various forms of campus activities and theme education, we can make students deeply understand the profound connotation of the idea of rule of law, and guide them to realize their life ideals by combining their own goals with social values.

\subsection{Deeply Implement the "Core Values Cultivation and Practice Project" to Strengthen the Foundation}

In the cultivation of people, the first thing is the formation of value system. The so-called "educating people first and cultivating people later" is the concentrated embodiment of China's core value system. In Colleges and universities, we should always implement the "core concept cultivation and practice project" in depth, consolidate the foundation, carry out in-depth practice, organically combine the concept of education and teaching, and firmly establish the idea of rule of law, It will run through all aspects of campus life, guide teachers and students to constantly strengthen the ideological and moral construction, firmly establish the ideological and moral concept. In the process of education implementation, we should focus on action, so that the idea of rule of law education can be subtly integrated into each student's idea. In depth practice of the "core values cultivation and practice project", mainly from the following aspects: first, always adhere to the law first, help students establish a correct core value system, guide the majority of teachers and students to practice the socialist core values, let it internalize in the heart, and firmly consolidate the concept system of rule of law education. Second, we should strengthen the ideological value system of the rule of law, bring the concept of the rule of law, social responsibility and the spirit of science and culture into the curriculum system of students' education and teaching. We should actively carry out activities to commemorate important anniversaries, such as carrying out education and publicity activities of popular science of the rule of law on the education day of the rule of law. The third is to organize a variety of publicity and education activities of the rule of law education, such as the theme education of scientific popularization of law on the rule of law education day, mainly to implement the concept of rule of law education, adhere to the value system of rule of law, and let the concept of rule of law and rule of law run through all aspects of social life. The fourth is to implement the policy of colleges and universities, so that students are not only limited to the classroom, but also pay attention to the society, practice their own social values from the society, and provide guidance for students according to the reality they face in social life, rather than traditional indoctrination.

\subsection{Carry out the "Cultural Project of Rule of Law" to Educate People with Culture and Culture}

In the cultivation of people, the first thing is the formation of value system. The so-called "educating people first and cultivating people later" is the concentrated embodiment of China's core value system. In Colleges and universities, we 
should always implement the "core concept cultivation and practice project" in depth, consolidate the foundation, carry out in-depth practice, organically combine the concept of education and teaching, and firmly establish the idea of rule of law, It will run through all aspects of campus life, guide teachers and students to constantly strengthen the ideological and moral construction, firmly establish the ideological and moral concept. In the process of education implementation, we should focus on action, so that the idea of rule of law education can be subtly integrated into each student's idea. In depth practice of the "core values cultivation and practice project", mainly from the following aspects: first, always adhere to the law first, help students establish a correct core value system, guide the majority of teachers and students to practice the socialist core values, let it internalize in the heart, and firmly consolidate the concept system of rule of law education. Second, we should strengthen the ideological value system of the rule of law, bring the concept of the rule of law, social responsibility and the spirit of science and culture into the curriculum system of students' education and teaching. We should actively carry out activities to commemorate important anniversaries, such as carrying out education and publicity activities of popular science of the rule of law on the education day of the rule of law. The third is to organize a variety of publicity and education activities of the rule of law education, such as the theme education of scientific popularization of law on the rule of law education day, mainly to implement the concept of rule of law education, adhere to the value system of rule of law, and let the concept of rule of law and rule of law run through all aspects of social life. The fourth is to implement the policy of colleges and universities, so that students are not only limited to the classroom, but also pay attention to the society, practice their own social values from the society, and provide guidance for students according to the reality they face in social life, rather than traditional indoctrination.

\subsection{Deeply Implement the "Network Construction Project", Share Resources and Give Full Play to Advantages}

In the cultivation of people, the first thing is the formation of value system. The so-called "educating people first and cultivating people later" is the concentrated embodiment of China's core value system. In Colleges and universities, we should always implement the "core concept cultivation and practice project" in depth, consolidate the foundation, carry out in-depth practice, organically combine the concept of education and teaching, and firmly establish the idea of rule of law, It will run through all aspects of campus life, guide teachers and students to constantly strengthen the ideological and moral construction, firmly establish the ideological and moral concept. In the process of education implementation, we should focus on action, so that the idea of rule of law education can be subtly integrated into each student's idea. In depth practice of the "core values cultivation and practice project", mainly from the following aspects: first, always adhere to the law first, help students establish a correct core value system, guide the majority of teachers and students to practice the socialist core values, let it in- 
ternalize in the heart, and firmly consolidate the concept system of rule of law education. Second, we should strengthen the ideological value system of the rule of law, bring the concept of the rule of law, social responsibility and the spirit of science and culture into the curriculum system of students' education and teaching [8]. We should actively carry out activities to commemorate important anniversaries, such as carrying out education and publicity activities of popular science of the rule of law on the education day of the rule of law. The third is to organize a variety of publicity and education activities of the rule of law education, such as the theme education of scientific popularization of law on the rule of law education day, mainly to implement the concept of rule of law education, adhere to the value system of rule of law, and let the concept of rule of law and rule of law run through all aspects of social life. The fourth is to implement the policy of colleges and universities, so that students are not only limited to the classroom, but also pay attention to the society, practice their own social values from the society, and provide guidance for students according to the reality they face in social life, rather than traditional indoctrination.

\subsection{Deeply Implement the "Teacher Team Construction Project", Set a Benchmark and Lead by Demonstration}

Secretary Xi Jinping has repeatedly stressed that the teacher as an important social guide, teachers should first have a good rule of law literacy, in a university, the rule of law literacy of teachers is a school law education value guidance and Legal Belief Cultivation guarantee, only teachers have certain legal literacy, then students will be deeply affected. Only in this way can the atmosphere of rule of law in the whole school be purified, which directly affects the learning and development of students' rule of law education, and is the basic guarantee of the cultivation of rule of law education. In the process of social development, we often hear that some colleges and universities find that there are serious problems in the value system of individual professors, which will affect the atmosphere of the whole university. In the face of this situation, colleges and universities should set up a certain mechanism of supervision, assessment and punishment. For some professors who cannot abide by the law, they should eliminate the teaching staff in time. The first is to strengthen teachers' professional theoretical quality. We should carry out the legal education of college students, establish and improve the long-term mechanism of legal education, strengthen teachers to establish a solid legal concept and strictly abide by the legal bottom line. Second, in the evaluation of teachers, we should not only take the academic as the evaluation content, but also strengthen the evaluation of Ideological and political literacy [14]. We should carry out regular training for the knowledge related to the rule of law education, conduct strict screening and assessment before teachers take up their posts, and conduct ideological literacy assessment after taking up their posts. Third, it is necessary to set a benchmark, to evaluate the advanced teachers, to publicize the excellent deeds of excellent teachers, to reward them, and to set up the power of example, which plays a certain role in forming a good 
value system for students. The fourth is to learn and innovate quality. We media era brings a new working mode for the society. Teachers should constantly improve their media literacy. Teachers should constantly sum up experience, use we media platform for legal education, and guide students to correctly use we media [15].

\section{Conclusions}

The Fourth Plenary Session of the 18th CPC Central Committee put forward a clear request to bring the rule of law education into the national education system. General Secretary Xi has repeatedly stressed the importance of the rule of law education. As the reserve force of national construction, college students should establish a correct concept of the rule of law and contribute their wisdom and strength to the construction of the rule of law. In the past, the cultivation of rule of law education in our country mainly depended on the single form of classroom indoctrination, which determined that there were still many problems in the cultivation of value guidance of rule of law education in our country. Students were in this environment for a long time, and the formed cognition of rule of law was also in a fixed mode.

As the main body of Ideological and political education, colleges and universities have a huge impact on students' Ideological and political awareness. In the past, because of this traditional mode, students only took ideological and political work as a simple classroom teaching and passively received it. After the coming of we media era, it also puts forward new requirements for the content of legal education. The past cultivation mechanism has been unable to meet the needs of college students for the value guidance of legal education in the new era. Therefore, it is necessary to build an efficient mechanism of all-round body education. Therefore, we have explored ten projects, which are important ways to carry out the rule of law education. They interact with each other, interact with each other, comprehensively consider various factors of high efficiency, cover all aspects of the rule of law education, and jointly serve the value guidance and Legal Belief Cultivation in the rule of law education. This is a sustainable and systematic strategic project, which is indispensable. On the premise of respecting the basic law of the development of the rule of law education, we should keep pace with the times, innovate according to the situation, integrate resources, coordinate development, and strive to build a new chapter in the cultivation of the rule of law education in the new era.

Although there are still many problems in the value guidance and Legal Belief Cultivation of the rule of law education in the we media era, the past single mode of rule of law education can no longer meet the development requirements of the new era, and the efficient and rapid social development also requires that the rule of law education can keep up with the pace of social development and face the complex forms of College Students' ideological changes, The state should focus on the construction of the rule of law education, cultivate the guarantee system and mechanism, and cooperate with all parties to realize the 
new stage of the development of the rule of law education.

\section{Conflicts of Interest}

The author declares no conflicts of interest regarding the publication of this paper.

\section{References}

[1] Kelsen, H. (1996) General Theory of Law and State. Encyclopedia of China Publishing House, Beijing.

[2] Cardoso, G. (2018) On the Education of College Students' Concept of Rule of Law in the Environment of We Media. Journal of Network Security Science, 25-31.

[3] Castells, M. and Gustavo, C. (2005) The Network Society: From Knowledge to Policy. Johns Hopkins Center for Transatlantic Relations, Washington, DC.

[4] Castel, M. (2009) The Rise of Network Society. Wiley-Blackwell, New Jersey.

[5] Negroponte, N. (2017) Digital Survival. Science News, 13 p.

[6] Alexander, M.C. (1993) Law-Related Education: Hope for Today's Students. Ohio Northern University Law Review, 20 p.

[7] Speirs, V.L. (1985) Law-Related Education: Making a Difference. Education Resources Information Center. https://files.eric.ed.gov/fulltext/ED296945.pdf

[8] Williamson, D., Minor, K.I. and Fox, J.W. (1997) Law-Related Education and Juvenile Justice. NCJRS Library, Washington.

https://www.ojp.gov/ncjrs/virtual-library/abstracts/law-related-education-and-juve nile-justice

[9] ABA Special Committee on Youth Education for Citizenship. (1981) Building the Bridge to the Law: How to Make Layers, Judges, Police and the Other Members of the Community a Part of Your Law-Related Education Program. ABA Publishing, Chicago.

[10] Kennedy, K.J. (1977) Citizenship Education and the Modern State. The Falmer Pess, New York.

[11] Alan, W. (2006) The Shame of American Legal Education. Vandeplas Publishing, Lake Mary.

[12] Denvir, C. (2016) Online and in the Konw? Public Legal, Young People and the Internet. Conputer \& Education, 92-93, 204-220.

https://doi.org/10.1016/j.compedu.2015.10.003

[13] Rodriguez, J.E., Greer, K. and Shipman, B. (2014) Copyright and You: Copyright Instruction for College Students in the Digital Age. The Journal of Academic Librarianship, 40, 486-491. https://doi.org/10.1016/j.acalib.2014.06.001

[14] Simpson, J. and Weiner, E. (2002) The Oxford English Dictionary. 2nd Edition, Oxford University Press, USA, 15-22.

[15] Robert, S. (1995) Essentials of Law-Related Education. American Bar Association's National Law-Related Education Resources Center, Leming, 5 p. 